\title{
The Relationless Japanese Society and the Practices of Belonging during the COVID-19 Pandemic
}

\author{
Tinka DELAKORDA KAWASHIMA*
}

\begin{abstract}
The aging of the population, lonely deaths (kadokushi), single-member households, and weak local bonds have been given as signs that Japan is now a "relationless society", or muen shakai. The term muen shakai has been used by the media to describe a society in which social isolation is intensified because of the lack of connection between immediate family members, more distant relatives, and local community. On the other hand, some sociological and religious studies on Japanese society have shown that it is precisely this social isolation that awakens the need for networking, and even excessive networking. This article studies what types of social relations became highlighted under the new conditions of recommended social isolation due to COVID-19. The Japanese government did not explicitly forbid and sanction socializing, leaving the responsibility and duty for common health to individuals as well as members of groups. It seems that the way in which Japanese society has fought COVID-19 largely depends on existing interpersonal ties and belonging to certain groups and communities. I look at sociocultural factors in social relations in Japan, to examine whether the ties and belonging to groups and communities, which has been more to the fore during COVID-19, is something new in the society or existed preceding the pandemic.
\end{abstract}

Keywords: Japanese society, COVID-19, social isolation, social identity, practices of belonging, muen shakai, relationless society, sociocultural factors

\section{Japonska družba brez odnosov in prakse pripadanja med pandemijo COVID-19}

\section{Izvleček}

Staranje prebivalstva, osamljene smrti, enočlanska gospodinjstva in šibke lokalne vezi nakazujejo, da je Japonska postala »družba brez odnosov« ali muen shakai. Izraz muen shakai mediji uporabljajo za opis družbe, v kateri je družbena izolacija še večja zaradi pomanjkanja odnosov med ožjimi družinskimi člani, bolj oddaljenimi sorodniki in lokalno skupnostjo. Po drugi strani pa so nekatere sociološke in religiozne študije japonske družbe pokazale, da prav ta družbena izolacija vzbuja potrebo po povezovanju in celo pretiranem

Tinka DELAKORDA KAWASHIMA, Hiroshima University.

Email address: tinka-delakorda@hiroshima-u.ac.jp

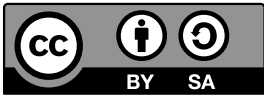


povezovanju. Ta članek preučuje, katere vrste družbenih odnosov so postale poudarjene v novih razmerah priporočene družbene izolacije zaradi širjenja COVID-19. Japonska vlada druženja ni izrecno prepovedala in sankcionirala, temveč je odgovornost in dolžnost za zdravje prepustila posameznikom kot članom skupin oziroma skupnosti. Zdi se, da je način, kako se je japonska družba borila proti COVID-19, v veliki meri odvisen od obstoječih medosebnih vezi ter pripadnosti določenim skupnostim. $V$ članku preverjam kulturne dejavnike $\mathrm{v}$ družbenih odnosih na Japonskem, da bi ugotovila, ali so vezi in pripadnost skupinam in skupnostim, ki so prišle v ospredje med COVID-19, v družbi nekaj novega ali so obstajale že pred pandemijo.

Ključne besede: japonska družba, COVID-19, socialna izolacija, družbena identiteta, prakse pripadanja, muen shakai, družba brez odnosov, sociokulturni dejavniki

\section{Introduction}

Since 2010, Japan has been described as relationless society or muen shakai; I aim to show in this paper that this may be a misconception. By looking at the COVID-19 responses, I argue that Japanese society is not relationless, but rather that social ties exist in Japan and did not just materialize because of the pandemic. Since the beginning of the crisis in 2020, both scholars' and public interest in social ties increased partly because such connections seemed to have had a significant impact on the ways different societies responded to the pandemic. Social connections were deemed necessary to foster the sense of belonging in the time of social isolation. One psychological study by American, Australian, and European researchers that focused on Western perspectives found that to increase feelings of belonginess and connectedness there was a need for a social identity approach during the COVID-19 crisis (Jetten et al. 2020). But this interpretation may not be applicable to the Japanese context. I aim to add to this research based on the existing ties and group relations, as observed in Japanese society. I argue that muen shakai is not an appropriate label in this context.

Many studies in the so-called "Western" societies identified social ties as negative, claiming societies need to start thinking in terms of "we" terms to fight the pandemic. In the newest integrated analysis based on experiences with COVID-19, psychologists discovered that it is necessary to foster feelings of belonging to others in times of crisis and self-isolation (Jetten et al. 2020). The authors further claimed that whether we survive self-isolation without serious health consequences or not does not depend as much on social contact and its frequency, but rather on the feeling of being connected to others (for example, mutual singing during isolation for community preservation) (ibid.). Thus the fight against COVID-19 leans on the feelings of connectedness and establishing mutual identities (ibid.). 
Examining Australian, European and American societies researchers found that this is not an easy task, since such societies historically depict such groups and group connections as being "toxic" (Le Bon in Jetten et al. 2020, 92). However, if we wish to protect people from the toxic consequences of isolation, we must point their focus to the currently overlooked significance of group connection. The influence for a negative understanding of group connection stems from arguments of writers such as Gustave Le Bon, who claimed that we lose our own "self" in crowds (Jetten et al. 2020, 92). Since the individual's "self" is seen as the only valid source of standards that guide our behaviour, the loss of "self" means the loss of every source of standards (Le Bon in Jetten et al. 2020). This view has been challenged by Henri Tajfel, who claimed that we need others as part of social identity theory (Tajfel and Turner 1979).

Tajfel defined social identity as "the individual's knowledge that he [or she] belongs to certain social groups together with some emotional and value significance to him [or her] of this group membership" (Tajfel 1978). By contrast, personal identity was defined as a person's sense of their individuality (e.g., their idiosyncratic abilities and tastes; Turner 1982). Jetten et al. $(2020,93)$ write that it is precisely in a crowd or a group that the radical consequences of social identity are shown. One does not lose his/her identity with the so-called model of the social identity of group functioning, but rather only moves from personal identity to social identity based on the change of environment (ibid.; Reicher 1984; 1987). Thus, we do not lose standards, as the foundations of our behaviour just transfer from personal standards to collective norms, values, and beliefs. A very clear example of such a transfer can be seen at the moment that a train breaks down (Jetten et al. 2020, 94). In the beginning, passengers are individuals that feel no connection to other passengers; however, when the train breaks down these individuals begin talking to each other, defending the rights of passengers, criticizing the railroad company, and trading food and drink (ibid.). Such feelings of collective values and the solidarity connected to it can be born in different circumstances, coincidentally or with intent-for example, when visiting holy places on holidays (Delakorda Kawashima 2016).

New psychology research results have shown that it is beneficial to view behavioural differences not as "characteristics of individuals", but rather as differences between the cultural systems they inhabit (Kitayama et al. 2009). Researchers explain that a cultural system can motivate individuals to show more or less individual versus collective behaviour, or independence/co-dependence, with individuals expressing this in different ways and to a different extent (ibid.). For example, we cannot say that Americans are characteristically independent and individualistic, while Japanese are dependent and group oriented. We can, however, observe what 
type of pro-social or collectively oriented functions are encouraged by different agents in these cultures or societies (and what response to that encouragement can be seen in individuals). These observations are interesting if we compare them to frequent perceptions of an individual's (non)religiousness as a characteristic of the culture to which an individual is subjected to. A strong awareness of belonging to a group can intensify individual's group membership (Staicov 2020) even if that awareness comes from the outside perceptions and claims.

In this article, I examine the literature on sociocultural factors in interpersonal relations, such as psychological, cultural, and spiritual perceptions of ties, to describe the current state of interpersonal bonds in Japanese society. Drawing on sociologists' and psychologists' reviews of what happened in societies in Australia, America, and Europe during the COVID-19 pandemic, I will look at interpersonal bonds that were showcased due to crisis response in the case of Japan. I first summarize some of the dominant findings of current global discussions on the COVID-19 pandemic and the significance of interpersonal ties and sense of belonging to others or society as a whole. Then, analysing the sociology, psychology and religious studies approaches, I aim to shed light on how researchers explain the state and significance of interpersonal ties and relations in contemporary Japanese society, and what historical religious-ethical foundations they ascribe to them.

The results of the analysis will provide researchers of social identity and relations with an insight into an alternative way people can perceive and affirm their connection to others. Based on the example of Japanese society, I point to the necessity of interdisciplinary research on social relations to better grasp the complexity of sociocultural impact factors on relationships, such as collective values, and spiritual understanding of ties.

\section{Background:The "Boost" Response (Non-Mandatory) Strategy in Japan}

A comparative analysis of the joint role that the institutional and cultural contexts have with regard to the development of state policy has shown that there is no common strategy against the spread of COVID-19 that would be appropriate for all countries (Yan et al. 2020). The Japanese government first released the "Basic Policies for Novel Coronavirus Disease Control” on 25th February 2020. These policies were revised four times since their release, especially after a state of emergency was declared in six prefectures (Saitama, Chiba, Tokyo, Kanagawa, Osaka, Hyogo and Fukuoka) on 7th April 2020. Although Japan has a unitary government system, subnational governments have gained much autonomy in the process of political development (Jacobs 2003). Japan did not impose any mandatory measures, partly 
because the central government does not have the legal means to sanction citizens or force them into lockdown for breaking regulations. Even after the state of emergency was expanded to all 47 prefectures on 16th April 2020, the Japanese government did not impose mandatory measures, such as the lockdowns implemented in other countries. Moreover, the emergency state was more of a symbolic gesture than a political action that would actually include the transfer of additional authority to local governments. For example, local policy interventions that directed the behaviour of individuals in Tokyo and in Hokkaido were issued before the recommendations of the national government during the state of emergency.

The basic response against COVID-19 in Japan includes four strategies: early detection, intensive care, securing medical services and the behavioural adjustments of its citizens. The Japanese government released guidelines on the "Three Cs" (closed spaces, crowds, close contacts) to provide the public with vital information on how to avoid infection, and guide or educate the public during the pandemic (Hayasaki 2020; Shaw et al. 2020). The risk of infecting groups is especially high when the "Three Cs" overlap. Therefore, governments in Japan recommended avoiding the "Three Cs" to the public, in order to minimize contact between people.

A proportionately less strict response designated to Japan is supposedly to a large degree the consequence of a decentralized regime and a tight cultural orientation (Shaw et al. 2020). In the context of a so-called "tight culture", citizens are assumed to be more prepared to follow government measures (Gaenslen 1986; Gelfand 2012) because they emphasize solidarity and rules (Poole 2019) and also take others into consideration. Gelfald et al. (2011) have shown that the looseness/tightness of a cultural orientation can influence an individual's consideration of social norms and influences the perception of responsibility of a citizen with regard to government interaction. Asian countries such as China, Taiwan, Korea, and Japan are supposedly associated by a tight culture due to their Confucian heritage. Through societal compliance with government measures such as containment and closure, these countries contained COVID-19, while elsewhere where a loose culture prevails, individuals show less tolerance for having their behaviour directed and are more inclined to self-responsibility and self-regulation (Gelfand 2012; Markus and Kitayama 1991).

\section{Social Identity and Solidarity}

In American, Australian, and European societies, Jetten et al. (2020) argued for the need to sweep away anti-collectivism and rationality, understood as the "enlightened pursuit of individual self-interest" (ibid., 15), in the context of COVID-19. 
The pandemic is said to have revealed the significance of belonging to a community for health during time in social isolation. For this reason, Jetten et al. (2020) argue in favour of using the social identity approach to examine COVID-19 responses, in other words to shift the emphasis from "me" to "we". This section discusses Western conceptualisations of social identity and solidarity, as these are often used to discuss this in the Japanese context. Because the individual/social identity may be inseparable in a society where individuals perceive themselves as connected and even inseparable from the group, concepts developed in the Japanese context are introduced, as these were relevant during the COVID-19 response: social ties en (including their opposite muen), the relational self kanjin, interpersonal relationships as religion, and practices of belonging.

\section{Pro-Social Behaviour and Solidarity in a Crisis}

It has been shown that certain individual characteristics, such as a personal sense of justice and social values, or demographic characteristics such as gender, age or income, are connected to a high tendency for pro-social behaviour (Zagefka and James 2015). However, as shown with spontaneous acts of solidarity (or sometimes hatred) in times of crises, we cannot simply explain behaviour based on relatively stable individual differences. It is necessary to explain it on a social level. Research has shown that people are seemingly more inclined to help and empathize with individuals considered as members of the same group than those outside of it. Thus, we may only display solidarity towards those with whom we share a social identity (Yzerbyt and Phalet 2020).

Viewed historically, during a crisis the most resilient communities are usually those with already strong and dense social networks and norms of trust and reciprocity. Such networks allow for a better readiness to cope with misfortune (Reininger et al. 2013), greater solidarity during catastrophes (Aldrich 2017) and better recovery after them (Aldrich 2012). However, communal and group solidarity can also develop spontaneously in the direct context of a crisis (ibid., 104). Sustaining this spontaneous solidarity long after the crisis has ended is of fundamental importance when facing long-term problems, such as the loss of social networks and livelihoods (Schonfeld and Demaria 2015). As a response to the numerous problems resulting from crises, groups and solidarity are said to be the most important-for practical reasons, as well as for the preservation of the spiritual and physical prosperity of the community (Jetten et al. 2020). 


\section{COVID-19: A Threat to Social Identity and the Groups of Belonging}

When people act in terms of their social identity, they interact with others based on an identity that they either share (as "us" ingroup members) or do not share (as "us" ingroup members versus "them" outgroup members) (Jetten et al. 2020). Times of crises influence how we draw lines between ourselves and others, between outsiders and friends, enemies and allies, foreigners and co-citizens. During COVID-19, the feeling of connection to a group and the idea of oneself as a member of a group came to the forefront (Jetten et al. 2020,60), and the various communities to which we belong (family, local community, state) were revealed. Different formulations of danger represented by COVID-19 seem to have consequences for a group. There is an increasing need to understand what it means to be a member of such groups and how group members are expected to behave. Questions that may arise are: What would be the best response of the community?, How do I best take care of the family?, What is the responsibility of teachers in given circumstances?, What is expected of the advocates for minorities? During the pandemic, the danger was often portrayed as not to stemming from the disease itself but by those outside of our groups (other countries or communities). Some politicians claimed that the best response could be to emphasize our mutual humanity in the fight against an external enemy, the virus, but the boundaries between different groups and between us and them remained strong.

\section{We can Only Be "Together Apart" by Strengthening Community and Belonging}

In psychological sciences, where the negative influences of social isolation on an individual's health are well known (see, for example, the anthropology of loneliness), researchers have tried to answer the question of how not to get sick in times of self-isolation, an issue facing many individuals all around the world. In the book Together Apart, Jetten et al. (2020) question why social isolation can be so detrimental for health and come to the realization that people are social beings in essence, drawing their self-value from their membership in a group. Identifying with a group justifies social aid and gives us a common goal and control, which are of critical significance for our health (ibid.). Belonging to a group and social activities should not be treated as "additional possibilities" that an individual chooses among other activities (ibid., 76). Rather, groups are of vital importance for healthy psychological functioning, because they allow us to express our social identities (ibid.). The authors also stress that numerous recommendations on how to stay connected in the time of self-isolation and avoid sickness (such as emphasizing the need for personal or video contact instead of using a phone or messages, 
and encouragement of everyday contact) miss the point, since they do not focus on the main role of social identities - the subjective feeling of belonging to some larger collective.

\section{Personal/Social Identity and Collectivist Cultural Values}

The extent to which individuals will experience themselves as separated from others, or independent/co-dependent, is determined by culture. Psychology researchers Markus and Kitayama (1991) recognized several modes of independence or co-dependence, and found systematic differences among individuals living in North American societies and those inhabiting the East-Asian cultural environment. Modes of independence included (among many others) representations of oneself as separated from others, emphasis on one's own uniqueness, giving priority to personal goals above the goals of others, and self-expression. Modes of co-dependence included representations of oneself in relation to others and in accordance with others, the sacrifice of one's own goals for others, and self-control. A person with a co-dependent self-image actively looks for relations with others, is attentive to the needs of others and wants to preserve and develop relationships (Bakan 1996). Even though the research made it evident that such personal inclinations dominate (Markus and Kitayama 1991), Kitayama et al. (2009; 2010) later cautioned that independence and co-dependence should be understood not as characteristics of individuals, as inferred by the term "self-image", but rather as characteristics of a cultural context inhabited by individuals.

A more recent multinational study claimed that the theoretical contrast between "independence" and "co-dependence" reflects a wider tendency of Western popular and scientific thought that defines individuality and sociality/collectivity as two opposing poles. The authors further argued that this perception ignores research in many disciplines that has shown that individuality and sociality are necessary and correlative aspects of human functioning in any cultural system (Oyserman, Coon, and Kemmelmeier 2002; Vignoles et al. 2016, 969; Guisinger and Blatt 1994; Kag itçibas, i 2005; Matsumoto 1999; Spiro 1993). Considering this mutual functioning of individuality and sociality, researchers focused on measuring how independent or co-dependent individuals are in Western and non-Western cultures, instead of asking them in what ways they are independent or co-dependent (Vignoles et al. 2016). Cultural systems can encourage individuals to think, feel or behave independently or co-dependently; however, it was stressed that individuals in the same system may adopt different ways of carrying out a comprehensive set of cultural tasks (Kitayama et al. 
2009). Collectivist cultural values seemingly cultivate a co-dependent self-image. As examples of values that are in accordance with the co-dependent "self" and collectivist cultures, Markus and Kitayama (1991) contrast (among other cultural examples) the Chinese emphasis on the collective welfare of all people, which takes precedence over individual welfare, interpersonal connection and kindness, with the Hispanic emphasis on acceptance and sensitivity towards the opinions of others and interpersonal understanding (Marčič and Kobal Grum 2009). In Japan, where a collective orientation prevails, people supposedly value harmonious interpersonal relationships with others (ibid.). Japan has been described as a tight culture (Gaenslen 1986; Gelfand 2012), and as such is expected to show high levels of compliance with government measures, as previously mentioned (Yan et al. 2020). However, taking recommendations seriously may have more to do with awareness of interdependence and belonging to a group. How people responded to the new conditions under the COVID-19 restrictions in relation to collective practices and rituals, can tell us something about the reality of collective orientation and interpersonal ties.

\section{The Relationless Japanese Society}

Reviewing the many activities or rituals that stimulate one's belonging to a community (of one's age group, school class, team), and heated responses to their cancelation, reveals the significance they have for the society. The persistent significance of these collective rituals suggests that the pandemic showed that Japanese society is not disconnected. However, labelling Japan as a disconnected society is still prevalent in and outside of the country, usually with the claim that demographic, social, and economic issues have transformed Japan into a society without connections, a "relationless society"(Allison 2013) or muen shakai (無縁社会).

The term muen (無縁) (together with kugai 公界 and raku 楽) was used in documents of the Japanese medieval period to describe places outside of secular control, such as temples, shrines, markets and bridges. In its wider usage, it describes people without earthly ties (Amino 2007). The word muen originates from Buddhist texts and means "to not be tied" or "being independent" (e.g., without karmic attachments); kugai describes temples as living spaces of those who cut secular ties, and raku describes the ideal world (or paradise). In the medieval period, these terms signified freedom; however, they lost their positive meaning with the centralization of the country by the end of the 16th century (ibid., 1), and the modern Japanese Dictionary Daijirin (Matsumura 1988) dictionary provides very different meanings for them. 
In modern times, the negative meaning of these terms is exemplified in by a 2010 NHK television documentary claiming that Japanese society had become muen shakai without connections (Nihon Hōsō Kyokai 2010). The main reason for introducing the term in 2010 was that 32,000 people had died a lonely death (kodokushi) in 2009 (Rowe 2011). Since then, the term muen shakai has become synonymous with new forms of social isolation. The media, editorial offices, academics, and newspapers have heavily criticized the Japan of the 21st century as being a society unable to take care of or even incapable of "recognizing" its deceased (ibid., 44). The evidence for the decline in social ties, writes Rowe, is the dilapidation of graves, the production, and maintenance of which was the responsibility of the wider family or familial ties within and between generations. Thus, if Japan were indeed a disconnected society, a pandemic would likely make the situation worse. However, the situation was not worse, which suggests there are still such bonds. However, what makes the bonds strong? To answer this question the current article looks into the spiritual foundations for "belief in dedicated bonds" between people, called en 縁.

\section{Social Relations Based on "Belief in Dedicated Bonds" en}

The pandemic showed that Japanese society is rather connected, as can be seen in people's compliance with the recommended, voluntary measures. In a disconnected society, recommendations made during the pandemic would not have functioned. That the recommendations functioned in Japan, can be explained because of already existing social ties. Social ties depend on how we see ourselves in relation to society, as discussed above. To claim that Japanese society has become a muen society means it was previously considered as connected by en. The opposing meaning of "untied" muen is "tied" en. The word en describes actual and mystical connections to another person in colloquial Japanese. To "have a bond" (縁 がある en ga aru) means to have a tie or to be connected accidentally or by fate. To “tie a bond” (縁結び en-musubi) means to find a partner or get married. The “regional” en tie (地縁 chien) describes the connection to one's birthplace or village, while families are connected with “blood” ties (血縁 ketsuen). The Japanese Language Dictionary (Shōgakutosho, ed. 1986) lists 35 phrases that begin with en, which speaks to the significance of this concept in the Japanese language and culture. $E n$ is at the same time also the fundamental principle of the Buddhist doctrine of “dependent origination" (縁起 engi, skt. Pratityasamutpāda), according to which, everything in the universe is physically and mentally connected to complex chains of causes and conditions or circumstances, and no single being exists independently (Boisvert 2004, 669-70). 
The significance and usage of the concept of $e n$ in Japanese culture explains how individuals see themselves in relation to society. In the doctrines and cultural meanings of $e n$, the identity of an individual is incorporated into a web of ties and connections. In other words, writes Rowe $(2011,46)$, the meaning of en denies the identity of the individual. En ties are multilayered; they are positive because they connect us to everyone and everything, but also negative because they attach us to others and limit our freedom. Thus, en is a matter of the living while its opposite pole or the absence of ties muen mainly concerns the dead who are abandoned by their heirs (無縁仏 muenbotoke). A person cannot be met by a worse fate than to become a muenbotoke or so-called “hungry spirit” (餓鬼 gaki). These supposedly travel the world as prosecuted and terrifying ghosts that cannot find peace and rebirth in the Buddhist Pure Land. Rowe finds that people in today's Japan still fear becoming muenbotoke and are even more afraid that they might cause a similar fate to their own ancestors (ibid.).

The en concept was implemented into the system of interpersonal relations as a new paradigm of research on "Japanese human relations" (Ishii 1998) and Ishii even proposed a so-called "Buddhist en perception of the world" and "en ethics". The belief in the existence of a dedicated bond en (the so-called en perception of the world) was widespread in Japan of the time (ibid., 112). On the basis of this belief, people shape, define and preserve interpersonal relationships, Ishii wrote, and proposed a relational examination of ties in Japan versus the analytical examination based on individualized relationships in Western societies. This approach was his answer to the blind acceptance of the American/Euro-centrist research paradigms adopted by many Japanese sociologists, psychologists, and cultural anthropologists of the time, whose scientific approaches leaned on Western values of individualism. Ishii criticized the proponents of individualism, who claimed that the relations based on independent individuals are more progressive than those of collectivistically oriented individuals (ibid., 109). Besides Ishii, Hamaguchi also tried to connect en and human relations into a system. He introduced the term "between people" or the "contextual person" kanjin 間人, and proposed that interpersonal relations in Japan should be studied with the concept of en and "interpersonal in-betweenness" (Hamaguchi 1985). Ishii was not the only one who cautioned against the trend among researchers of the time to blindly apply the values of individualism. The well-known psychologist Rosenberger $(1992,2)$ critiqued ethnocentric views of interpersonal relations that idealize democracy with regard to seeing decision making entrusted to rational individuals in Western societies, while criticizing how non-Western societies control cohesion through collectiveness and relations based on superstition. Rosenberger promoted ethnorelativism in research into interpersonal relations, and argued that Western researchers need 
to understand that realizing oneself is achieved through connection with others. She also warned of the difference in understanding interpersonal relations. In Western views of relations, it is often expected that they are purposely controlled and manipulated to achieve personal goals. This was supposedly foreign to the Japanese, who consider relationships as freely given and naturally evolving. Similar conclusions were shown by Prunty, Klopf and Ishii (1990) in their comparative study of the practice of argumentation as an element in interpersonal relations. They write that argumentation is foreign to the Japanese, they are not used to arguing and believe it can destroy the balance between the participants in the conversation. Americans, on the other hand, because of their positive view of argumentation, do not destroy relations with it, even if relations are temporarily shaken (ibid. 1990, 78). The research discussed above shows the stubborn tendency of painting a simplistic, black-or-white picture of Western and non-Western, Japanese and American behavioural characteristics. Yet, the evidence from Japan still shows the tendency among people to maintain balance and accord in interpersonal relations and taking other peoples' possibly different opinions into consideration, although this may be done by keeping one's own opinion to oneself. Such attitudes to interpersonal relationships and ties may be rooted in the belief in a mystical en connection.

\section{Individuals in Relation to Others, Loneliness, and Suicide}

Because in Japan social relations are strongly linked to rituals (e.g., graduation ceremonies, school trips, and afterschool activities) to maintain a sense of commitment and belonging, the cancelation of these rituals intensified social isolation, which could partly be seen in an increase in suicides. Considering that the suicide rate had been decreasing in the last ten years, one may argue that the society had even been improving social connections (Tanaka and Okamoto 2021), and losing these during the pandemic might have led to the rise in suicides.

How individuals experience themselves in relation to others, the community and society in general, can be seen as a spectrum, one extreme of which is the opposite of psychological health, pushing individuals towards suicide-i.e., fear of social abandonment. From psychological and anthropological research, we know that the fear of social abandonment and that nobody will need us anymore are the main reasons for suicide in Japanese society (Ozawa-de Silva and Parsons 2020). At the same time, research has shown that the social usefulness of an individual is the main precondition for a positive self-image, welfare, and a positive attitude towards life in many Japanese individuals (ibid.). Studies on suicide in Japan speak 
of the necessity of belonging and mutual recognition. However, to what degree are the need for belonging and mutual recognition universal? How was the Internet used to sustain the sense of belonging in Japan?

Researchers identify a lack of relations and feeling of not being useful as the main reasons for loneliness, which has been recognized as one of the major challenges facing public health today (Ozawa-de Silva and Parsons 2020). The authors try to look beyond the aspect of public health and handle loneliness as a social phenomenon that affects everyone. They write that feelings of loneliness, rejection, and social abandonment are all part of the human experience, and there is even talk of an epidemic of loneliness in recent times. Loneliness is not a sickness but a natural state that speaks of the fact that humans are social beings. With the COVID-19 pandemic, our need for connection was brought into focus. If we neglected relations and experienced loneliness before the pandemic, mandatory isolation reminded us of the significance of social connection and forced us to develop ties through the Internet. Online, many experienced more connection to others with whom they did not have a lot of interactions in everyday life before the pandemic. Evolutionary psychology provides strong evidence that the reasons for the common appearance of loneliness in our lives are universal, since they stem from the basic need for belonging and mutual recognition (Cacioppo and Patrick 2008; de Waal 2010; Rochat 2009; Ozawa-de Silva 2020). To sustain a sense of belonging and soften the effect of self-isolation, various institutions in Japan used the Internet to maintain established collective rituals. In some cases, e.g., schools, instead of completely cancelling rituals, teachers replaced the actual events with hybrid ones (see fig. 2). Such efforts show how important these rituals and related ties are in contemporary Japanese society.

\section{Interpersonal Relations and the Practice of Belonging}

During the COVID-19 pandemic, the sense of belonging to communities was shown to work online, and those communities were not necessarily physical. From previous research on Japanese youth and the use of cell phones, we see that communities already existed in the networks of young people (Nakajima, Himeno and Yoshii 1999).

Here it is important to point out the sociological studies that note the peculiarities of contemporary interpersonal relations in Japan, because of the decline of traditional communities based on en. Doi (2014) claims that in today's society with weak traditional family "blood bonds" ketsuen and "regional bonds" chien, communities and organizations, such as schools and companies, lose their regulatory 
power over individuals. The young are not born into already existing human relations that provide social belonging, they must create their own relations and have to constantly maintain them by themselves (ibid.). Thus, young people strive to create and maintain bonds in new creative ways, and the Internet helps them expand their physical connections. Longing for strong interpersonal ties (Fujiwara 2019) and the desire for recognition forces young people into excessive networking. A group of sociologists used a longitudinal study and found that the factors that condition happiness and love had changed in the interpersonal relations of young Japanese people (Fujimura, Asano and Habuchi 2016). A well-known ethnographic study of young people and their use of cell phones in Japan found that they provide "a constant intimate community" with close friends and partners (Nakajima, Himeno and Yoshii 1999). Such communities are seemingly especially created by young people who have moved to cities and become independent, and thus no longer have strong ties to the community in their home regions. Connection with close groups is preserved through frequent meetings on the phone where they feel a 24-hour psychological connection (ibid., 90).

Connecting and forging ties via the Internet also existed before COVID-19, as the above research shows. The need to constantly connect over the Internet relates to the need for interpersonal relations and belonging. This does not imply that there is no need for physical connection, though. Social ties are expressed through physical presence, especially in Japan, where being present shows commitment, as seen, for example, in a person's posture. People forced into remote working to avoid the spread of COVID-19 stated that they liked to work at home, but that being present at the workplace is important. This tendency has been observed regardless of the culture, but it may be more pronounced in interdependent societies. In quantitative psychological research, a positive connection was found between emotional support and well-being in interdependent cultures, namely among Japanese and Filipinos (Uchida et al. 2008; Kitayama et al. 2010; Chang et al. 2016). Thus, taking these physical expressions away in Japan presented a significant issue, and during COVID-19 many employees kept coming to work in spite the formal possibility to stay at home. Therefore, rather than highlighting the increased need to connect as something that materialized due to COVID-19, research shows that this need was already there.

\section{Practicing Belonging as Religion}

The COVID-19 pandemic highlighted the social group-based human relationships, which according to Japanese scholars of religion are the religion in Japan. Even 
though Japan has been widely perceived as nonreligious, some researchers claim that religion in Japan has long been, in fact, a religion of interpersonal relationships. Fujiwara $(2019,147)$ shows that what she calls the "relationship turn" is a trend not only seen at non-religious holidays and rituals, but also in spiritual culture and institutionalized religion. This trend is evident as a sort of obsession in Japanese society with tsunagariつながり (relations, connectivity) and shonin 承認 (recognition).

Human relationships are not only portrayed as religion in Japan. In recent research on British society, Day (2011) shows religion as being based on interpersonal relations grounded on "the belief in belonging" as pursued in groups such as the family, local community, friends, and co-workers (ibid., 181). This is another research that supports the claim of the universality of the need for belonging. While people in Japan today, particularly the youth, practice belonging in an intimate sphere, it was once religion as practices of belonging that regulated the public sphere (Fujiwara 2019). As an example Fujiwara gives Yanagawa's explanation of the Bon festivities for ancestors' souls, who stated that the religion of the Japanese is not a belief in a god or belonging to a religious institution, but the "religion of interpersonal relations” (ningenkankei no shükyō人間関係の宗教) (Yanagawa in Fujiwara 2019, 126).

However, we can say that such a religion is practised and preserved even today. Interpersonal ties and stressing the sense of belonging can be seen in multiple rituals maintained by groups not only in the intimate sphere, but in various aspects of social life in Japan, such as at school and the workplace, and in relation to sports, art, and leisure.

Based on personal communication of the author with students at Japanese schools and universities, such rituals are practiced in classrooms and afterschool activities (bukatsu 部活) from elementary to high school. They encourage integration and the solidarity of the group, for example through frequent usage of common greetings, the use of specific speech and intonation, mandatory following of the rules of the group, and the experience of belonging to a group as the highest goal. Such cases show that practices of belonging resembling religion have been sustained in the public sphere.

The belief of belonging to a group is also emphasized through expressions like the aforementioned "connection" tsunagari, "bond” kizuna 紏, "mutual recognition" sōgō shōnin 相互承認 and “affection or empathy” dōkan 共感. These expressions are also often the subject of academic and public discourses in Japan (Fujiwara 2019, 127) (fig. 1). For example, in Japanese public schools each class has a common goal that is meant to create a community for the class. Figure 1 shows a classroom with the class goal— the framed character 絆—placed above the blackboard. 


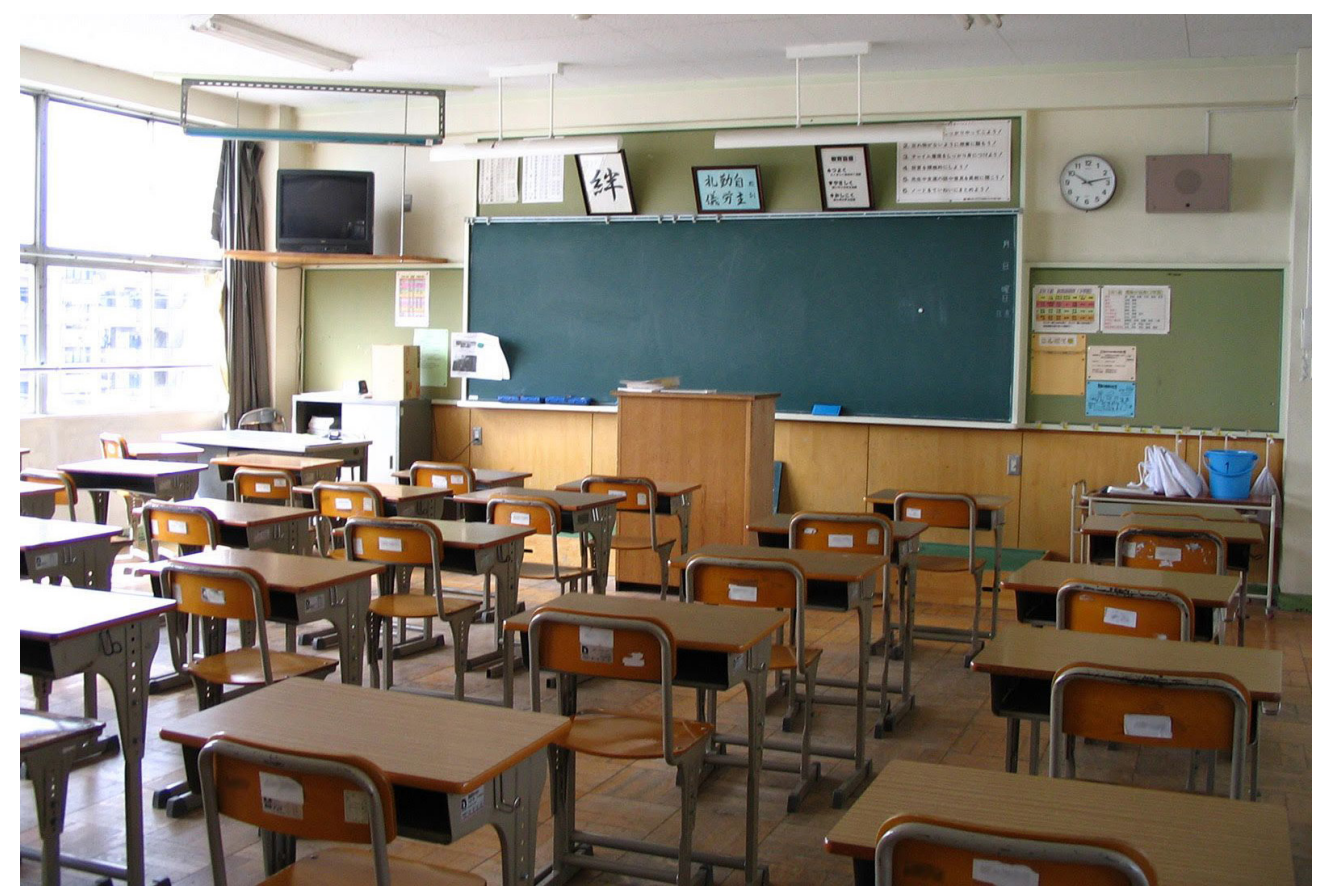

Figure 1. A typical classroom in a Japanese public school with the character for "bond" kizuna (絆) framed on the left above the board. (Source: Wikipedia, open access, https://commons. wikimedia.org/wiki/File:Classroom2.jpg)

\section{Conclusion: The Crises Revealing the Need for Social Rehabilitation}

Some notable changes in the social structure of Japanese society, e.g., aging of the population and weakening of family and regional ties, have led to depicting it as disconnected, or muen shakai. Using the response to the COVID-19 pandemic as a case study, this article argued against this assumption by examining the practices showing the persistent significance of social ties in Japan. Drawing on the recent research in the field of religious studies, the article calls these practices of belonging.

The re-establishment of ties, the so-called "relational turn" in Japan, emerged a decade ago in spiritual culture, non-religious rituals and holidays, and even in institutionalized religion, as shown by researchers in the field (Sakurai 2015) after the 2011 earthquake and tsunami catastrophe in the Tohoku area. So-called clinical religions provided help to the affected in Fukushima, mainly by actively listening to them. After the catastrophe, rather than seeking psychological or spiritual help, people needed care that included social recognition as well as 
self-recognition. The activities that included such care were seen as potentially re-building interpersonal relationships in communities that had fallen apart (ibid., 29). Even in the time of the COVID-19 pandemic, it became evident that existing values of connection, collegiality, and belonging were activated within groups or communities. In Japan, the closing of schools due to COVID-19 almost coincided with the end of the school or academic year, which meant that students were robbed of the graduation ceremonies within their communities. To keep the ceremonies, the teachers modified them to comply with measures to prevent the spread of COVID-19 (fig. 2). This example shows that people are aware of the importance of such rituals and their significance for a sense of belonging.

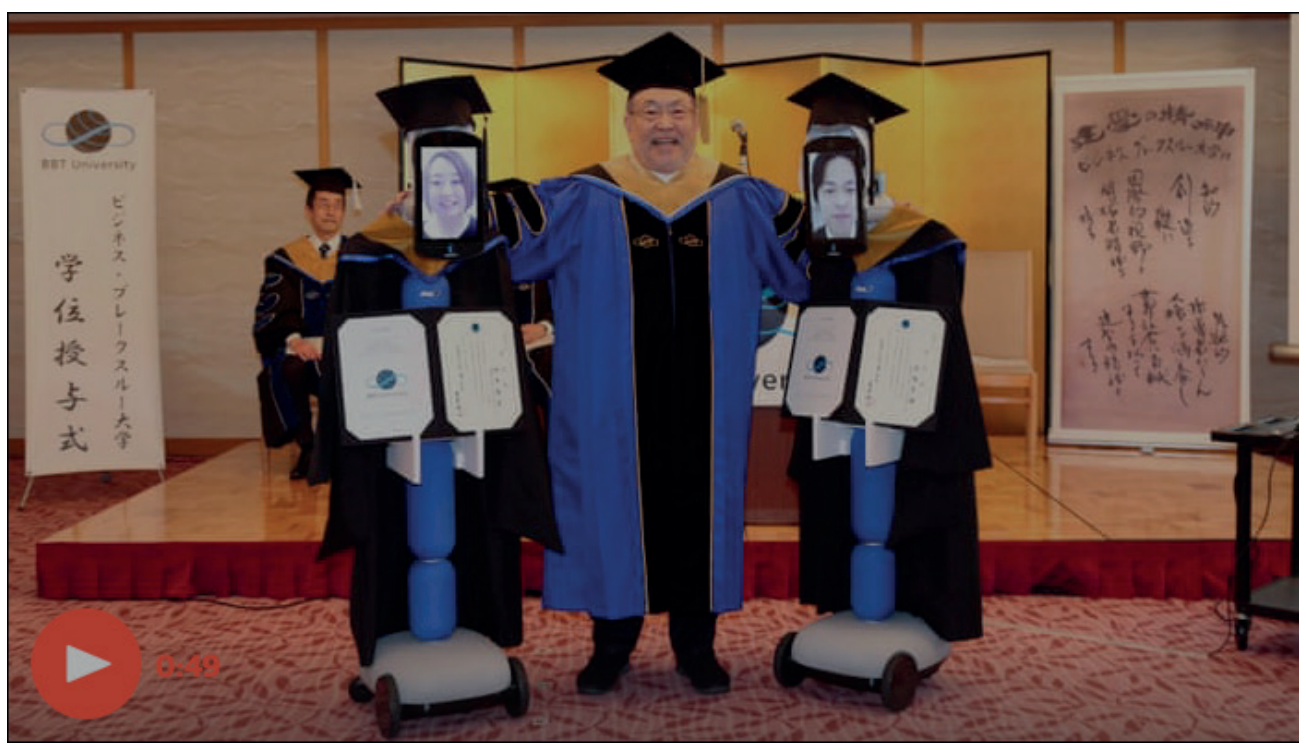

Figure 2. "Robots replace students at Japan graduation ceremony amid COVID-19." (Source: The Guardian, April 8, 2020, open access)

The government strategy of fighting the spread of COVID-19 through the transfer of competencies and responsibilities to groups and individuals has been implemented in the active provision of instructions on behaviour through the media of the institutions and communities that individuals are part of. In many societies and communities around the world people followed their social roles and the "appropriate" behaviour connected to them (a parent functions as expected of parents; a teacher in accordance with the responsibilities of a teacher and the school), 
in Japan the emphasis could have been on fulfilling expectations as the members of the groups, workplaces, schools, etc. that people belong to.

To conclude, the article showed that labelling Japan as a disconnected muen society was too rushed, and we may now have an opportunity to move away from this label because the pandemic showed it does not accurately reflect the situation in Japanese society. The traditional ways of interpersonal connection have been replaced by new ways in new social contexts, and still maintain their significance for the people, as the responses due to cancelation of events that promote those ties revealed. We may thus speak of Japan not as muen shakai, but rather as "en shakai", a connected society.

\section{Implications of the Study}

Did this study show that Japan is collectivist and co-dependent society? What are the implications of its findings? In the overview of various aspects of the significance of social connectedness presented above, it was shown that the transition between personal and social identity, as well as different perceptions of the individual in relation to society, need to be taken into account in the design and analysis of research, as well as in the implementation of social arrangements in times of crisis.

Interest in research on interpersonal relations as fundamental for human spiritual, as well as physical well-being, and its significance for the meaning of life, has been present in different scientific disciplines for some time (Fleming and Baum 1986; Uchida et al. 2008; Kitayama et al. 2010; Chang et al. 2016). These psychological quantitative studies show that people in Asian cultures usually strive for connection, relationism and co-dependence that originates from the image of oneself not as an independent (separated) entity, but rather inherently connected to others (Berry et al. 1992, 94; Oyserman, Coon and Kemmelmeier 2002). The present study emphasized the role of cultural and social systems that influence individuals' responses, so individuals' characteristics should not be treated as inherently present. The research showed there is a universal need for belonging, although it is pursued in different ways, by different agents, in private and public spaces. A comparative study of social relations observed during the crisis could be particularly useful among cultures with more common denominators in sociocultural patterns (e.g. comparison with the relational self in the Chinese context, Rošker 2021).

Another area of interest is to study the meaning of the belief in en for interpersonal relations using a comparative study of cultures with a strong presence of this belief. Of course, one must also take into account the aforementioned argument 
that a culture can only encourage an individual to act, and how and to what degree they will respond and accept a culture depends on the individual (Kitayama et al. 2009). In newer research of cross-cultural psychology, it was shown that it is more reasonable to study interpersonal relations on the basis of the openness of individuals (self-disclosure), which depends on different levels of the "mobility of relations" within the same culture and between cultures rather than the dichotomy of independence and co-dependence (Schug, Yuki, and Maddux 2010). Moreover, psychology studies on the Japanese context for adolescent identity showed that "contemporary Japanese adolescents value individualistic collectivism, pursuing individuality within a collectivistic society" (Matsumoto 2002 cited in Sugimura 2020). However, the emerging individualism of younger people is not in tune with the wider society that is largely collectivist, in that it values the traditional homogeneity of the Japanese (Sugimura 2020).

Based on a multidisciplinary approach to social relations, this study exposed the weaknesses of claims for muen shakai based on assumptions from particular disciplines that saw the evidence for their claim in the fall of traditional bonds, graves, and public rituals, and overuse of the Internet. The case study of Japan contributes to the research on social relations and ties by suggesting approaching them as practices of belonging, which are maintained through physical presence/attitude and expanded via the Internet within various communities of belonging. It is in the area of these rituals where collective values and interdependence kept being nourished. The significance of the social ties as practices of belonging in the context of Japanese society suggests that in sociological and psychological research, the individual's mental health issues caused by crises must be observed and considered in relation to the individual's need for belonging.

\section{Acknowledgment}

I am grateful to Dr. Adina Stajcov for valuable comments on this article. The research for this paper was supported by the Slovenian Research Agency (ARRS) in the framework of the research core funding Asian Languages and Cultures (P6-0243).

\section{References}

Aldrich, Daniel P. 2012. "Social, Not Physical, Infrastructure: The Critical Role of Civil Society after the 1923 Tokyo Earthquake.” Disasters 36: 398-419.

Aldrich, Daniel P. 2013. "Rethinking Civil Society-State Relations in Japan after the Fukushima Accident." Polity 45: 249-64. 
. 2017. "The Importance of Social Capital in Building Community Resilience." In Rethinking Resilience Adaptation and Transformation in a Time of Change, edited by W. Yan, and W. Galloway, 357-64. Berlin: Springer.

Allison, Anne. 2013. Precarious Japan. Durham, NC: Duke University Press.

Amino, Yoshihiko. 2007. "Medieval Japanese Constructions of Peace and Liberty:

Muen, kugai, and raku." International Journal of Asian Studies 4 (1).

Bakan, David. 1996. The Duality of Human Existence. Boston, MA: Beacon Press.

Berry, John W., Ype H. Poortinga, Marshall H. Segall, and Pierre R. Dasen. 1992. Cross-Cultural Psychology: Research and Applications. Cambridge: Cambridge University Press.

Boisvert, Mathieu. 2004. "Prati tya Samutpada (Dependent Origination)." In Encyclopedia of Buddhism, edited by Robert E. Buswell, jr., vol. 2, 669-70. New York: McMillan Reference USA.

Cacioppo, John T., and William Patrick. 2008. Loneliness: Human Nature and the Need for Social Connection. New York: WW Norton \& Company.

Chang, Melissa X.-L., Jolanda Jetten, Tegan Cruwys, Catherine Haslam, and Nurul Praharso. 2016. "The More (Social Group Memberships), the Merrier: Is This the Case for Asians?” Front. Psychol 7: 1001.

Day, Abby. 2011. Believing in Belonging: Belief and Social Identity in the Modern World. Oxford: Oxford University Press.

de Waal, Frans. 2010. The Age of Empathy: Nature's Lessons for a Kinder Society. New York: Broadway Books.

Delakorda Kawashima, Tinka. 2016. "The Healing Jizō: Sōtō Zen Kōganji Temple Adapting to Varying Social Conditions." Taiwan Journal of East Asian Studies 13: 77-105.

2019. "Teachers and Ethics: Developing Religious Self-Awareness.” Bulletin Graduate School of Education Hiroshima Univ. Part I, 68: 91-97.

Doi, Takayoshi. 2014. Tsunagari o aorareru kodomotachi: Netto izon to ijime mondai o kangaeru つながりを煽られる子じもたち一ネット依存といじめ問題 を考える (Children Who Are Incited to Be Connected to Each Other: Thinking about the Problem of Cyber Dependence and Bullying). Tokyo: Iwanami.

Fleming, Raymond, and Andrew Baum. 1986. "Social Support and Stress: The Buffering Effect of Friendship." In Friendship and Social Interaction, edited by Valerian Derluga, and Barbara Winstead, 207-26. New York: Springer-Verlag.

Fujimura, Masayuki, Tomohiko Asano, and Ichiyo Habuchi, eds. 2016. Gendai wakamono no kōfuku: Fuan shakai o ikiru 現代若者の幸福一不安社会を生 きる (The Happiness of Modern Youth: Living in an Anxious Society). Tokyo: Kōseishakōseikaku. 
Fujiwara, Satoko. 2019. "Practicing Belonging? Non-Religiousness in Twenty-First Century Japan." Journal of Religion in Japan 8: 123-50.

Gaenslen, Fritz. 1986. "Culture and Decision Making in China, Japan, Russia, and the United States." World Politics 39 (1): 78-103.

Gelfand, Michele J., Jana L. Raver, Lisa Nishii, Lisa M. Leslie, Janetta Lun, Ben Chong Lim, and Susumu Yamaguchi. 2011. "Differences between Tight and Loose Cultures: A 33-Nation Study.” Science 332 (6033): 1100-04.

Gelfand, Michele J. 2012. "Culture's Constraints: International Cifferences in the Strength of Social Norms." Current Directions in Psychological Science 21 (6): 420-24.

The Guardian. 2020. "Robots Replace Students at Japan Graduation Ceremony Amid Covid-19." The Guardian, April 8, 2020. Accessed October 12, 2021. https://www.theguardian.com/world/video/2020/apr/08/robots-replace-students-at-japan-graduation-ceremony-amid-covid-19-outbreak-video.

Guisinger, Shan, and Sidney J. Blatt. 1994. "Individuality and Relatedness: Evolution of a Fundamental Dialectic." American Psychologist 49: 104-11.

Hamaguchi, Esyun. 1985. "A Contextual Model of the Japanese: Toward a Methodological Innovation in Japan Studies.” Journal of Japanese Studies 11 (2): 289-321f.

Hayasaki, Erika. 2020. "Covid-19: How Japan Squandered Its Early Jump on the Pandemic.” BMJ (Clinical Research Ed.): 369, m1625.

Ishii, Satoshi. 1998. "Developing a Buddhist En-Based Systems Paradigm for the Study of Japanese Human Relationships." Japan Review 10: 109-22.

Jacobs, A. J. 2003. "Devolving Authority and Expanding Autonomy in Japanese Prefectures and Municipalities." Governance 16 (4): 601-23.

Jenkins, Janis H., Giselle Sanchez, and Olga L. Olivas-Hernández. 2020.”Loneliness, Adolescence, and Global Mental Health: Soledad and Structural Violence in Mexico." Transcultural Psychiatry 57 (5): 673-87.

Jetten, Jolanda, Stephen D. Reicher, S. Alexander Haslam, and Tegan Cruwys, eds. 2020. Together Apart: The Psychology of COVID-19. Thousand Oaks, CA: Sage. $\mathrm{Kag}$ itçibas,i, Çigdem. 2005. "Autonomy and Relatedness in Cultural Context: Implications for Self and Family." Journal of Cross-Cultural Psychology 36: 403-22.

Kitayama, Shinobu, Hyekyung Park, A. Timur Sevincer, Mayumi Karasawa, and Ayse K. Uskul. 2009. "A Cultural Task Analysis of Implicit Independence: Comparing North America, Western Europe, and East Asia." Journal of Personality and Social Psychology 97 (2): 236-55.

Kitayama, Shinobu, Mayumi Karasawa, Katherine B. Curhan, Carol D. Ryff, and Hazel Markus. 2010. "Independence and Interdependence Predict Health and Wellbeing: Divergent Patterns in the United States and Japan." Frontiers in Psychology 1. https://doi.org/10.3389/fpsyg.2010.00163. 
Le Bon, Gustave. 1895/1960. The Crowd: A Study of the Popular Mind. New York: Viking.

Marčič, Renata, and Darja Kobal Grum. 2009. "Povezanost samopodobe in samospoštovanja z agresivnostjo." Psibološka obzorja (Horizons of Psychology) 18 (4):59-71.

Markus, Hazel R., and Shinobu Kitayama. 1991. "Cultural Variation in the Self-Concept." In The Self: Interdisciplinary Approaches, edited by George R. Goethals, and Jaine Strauss, 18-47. New York: Springer Verlag.

Matsumoto, David.1999. "Culture and Self: An Empirical Assessment of Markus and Kitayama's Theory of Independent and Interdependent Self-Construals.” Asian Journal of Social Psychology 2: 289-310.

Matsumura, Akira, ed. 1988. Daijirin 大辞林 (Japanese Dictionary). Sanseido. Tokyo. Nakajima, Ichiro, Keiichi Himeno, and Hiroaki Yoshii. 1999. "I dō-denwa Riyō no Fukyū to sono Shakaiteki Imi 移動電話の普及とその社会的意味 (Diffusion of Cellular Phones and PHS and Their Social Meaning)." Tsūshin Ga$k k a i$-shi (Journal of Information and Communication Research) 16 (3).

Nihon Hōsō Kyokai (NHK) Muen Shakai Purojekuto Shuzaihan, ed. 2010. Muen Shakai “Muenshi” Sanman ni sen nin no Shougeki. 無縁社会: “無縁死”三二 千人の衝 (A Society Without Relationships: The Impact of 32,000 "Deatbs Without Relationships"). Tokyo: Bungei Shunjuu.

Oyserman, Daphna, Heather M. Coon, and Markus Kemmelmeier. 2002. "Rethinking Individualism and Collectivism: Evaluation of Theoretical Assumptions and Meta-Analyses." Psychological Bulletin 128 (1): 3-72.

Ozawa-de Silva, Chikako. 2020. "In the Eyes of Others: Loneliness and Relational Meaning in Life among Japanese College Students." Transcultural Psychiatry 57 (5): 623-34.

Ozawa-de Silva, Chikako, and Michelle Parsons. 2020. “Toward an Anthropology of Loneliness." Transcultural Psychiatry 57 (5): 613-22.

Poole, Ed G. 2019. "How Institutional Culture Trumps Tier Effects: Evidence from Government Responsiveness to FOI Requests." Journal of Public Administration Research and Theory 29 (2): 210-26.

Prunty, Alicia M., Donald W. Klopf, and Satoshi Ishii. 1990. "Argumentativeness: Japanese and American Tendencies to Approach and Avoid Conflict." Communication Research Reports 7 (1): 75-79.

Reicher, Stephen D. 1984. "The St. Pauls' Riot: An Explanation of the Limits of Crowd Action in Terms of a Social Identity Model." European Journal of Social Psychology 14: 1-21.

Reicher, Stephen D. 1987. "Crowd Behaviour as Social Action." In Rediscovering the Social Group: A Self-Categorization Theory, edited by John C. Turner, Michael A. Hogg, Penelope J. Oakes, Stephen D. Reicher, and Margaret S. Wetherell, 171-202. Oxford: Blackwell. 
Reininger, Belinda M., Mohammad H. Rahbar, Min Jae Lee, Zhongxue Chen, Sartaj R. Alam, Jennifer Pope, and Barbara Adams. 2013. "Social Capital and Disaster Preparedness among Low Income Mexican Americans in a Disaster Prone Area." Social Science and Medicine 83: 50-60.

Rochat, Philippe. 2009. Others in Mind: Social Origins of Self-Consciousness. Cambridge, UK: Cambridge University Press.

Rosenberger, Nancy R., ed. 1992. Publications of the Society for Psychological Anthropology. Japanese Sense of Self. Cambridge University Press.

Rošker, Jana S. 2021. “Kitajska filozofija življenja, relacijska etika in COVID-19.” Asian Studies 9 (3): 323-40.

Rowe, Mark M. 2011. Bonds of the Dead: Temples, Burial, and the Transformation of Contemporary Japanese Buddhism. Chicago: The University of Chicago Press.

Sakurai, Yoshihide. 2015. “Keichō suru bukkyō 傾聴する仏教 (A Buddhism of Listening)." Shūkyō to shakai kōken (Religion and Social Service) 5 (1): 29-53. Schonfeld, David J., and Thomas Demaria. 2015. "Providing Psychosocial Support to Children and Families in the Aftermath of Disasters and Crises." Pediatrics 136: e1120-e30.

Schug, Joanna, Masaki Yuki, and William Maddux. 2010. "Relational Mobility Explains between- and within-Culture Differences in Self-Disclosure to Close Friends.” Psychological Science 21 (10): 1471-78.

Shaw, Rajib, Yong-kyun Kim, and Jinling Hua. 2020. "Governance, Technology and Citizen Behavior in Pandemic: Lessons from COVID-19 in East Asia." Progress in Disaster Science 6: 1-10.

Shōgakutosho, ed. 1986. Kokugo daijiten gensen 国語大辞典言泉 (Japanese Language Dictionary). Tokyo: Shōgakkan.

Spiro, Melford E. 1993. "Is the Western Conception of the Self "Peculiar" within the Context of the World Cultures?" Ethos 21: 107-53.

Staicov, Adina. 2020. Creating Belonging in San Francisco Chinatown's Diasporic Community: Morphosyntactic Aspects of Indexing Ethnic Identity. Cham: Palgrave Macmillan.

Sugimura, Kazumi. 2020. "Adolescent Identity Development in Japan.” Child Dev Perspect 14: 71-77.

Tajfel, Henri, and John C. Turner. 1979. "An Integrative Theory of Intergroup Conflict." The Social Psychology of Intergroup Relations 33 (47): 74.

Tajfel, Henri. 1978. “The Achievement of Inter-Group Differentiation.” In Differentiation between Social Groups, edited by Henri Tajfel, 77-100. London: Academic Press.

Tanaka, Takanao, and Shohei Okamoto. 2021. "Increase in Suicide Following an Initial Decline during the COVID-19 Pandemic in Japan." Nat Hum Behav 5: 229-38. 
Turner, John C. 1982. “Toward a Cognitive Definition of the Group.” In Social Identity and Intergroup Relations, edited by Henri Tajfel, 15-36. Cambridge: Cambridge University Press.

Uchida Yukiko, Kitayama Shinobu, Batja Mesquita, Jose Alberto S. Reyes, and Beth Morling. 2008. "Is Perceived Emotional Support Beneficial? Well-Being and Health in Independent and Interdependent Cultures." Personality and Social Psychology Bulletin 34 (6): 741-54.

Vignoles, Vivian. L. et al. 2016. "Beyond the 'East-West' Dichotomy: Global Variation in Cultural Models of Selfhood." Journal of Experimental Psychology: General 145 (8): 966-1000. doi: 10.1037/xge0000175.

Wilder-Smith, Annelies, and David O. Freedman. 2020. "Isolation, Quarantine, Social Distancing and Community Containment: Pivotal Role for Old-Style Public Health Measures in the Novel Coronavirus (2019-nCoV) Outbreak." Journal of Travel Medicine 27 (2).

Woodhead, Linda. 2016. "The Rise of 'No Religion' in Britain: The Emergence of a New Cultural Majority." Journal of the British Academy 4: 245-61.

Yan, Bo, Xiaomin Zhang, Long Wu, Heng Zhu, and Bin Chen. 2020. "Why Do Countries Respond Differently to COVID-19? A Comparative Study of Sweden, China, France, and Japan." The American Review of Public Administration 50 (6-7): 762-69.

Yanagawa, Kei'ichi, and Yoshiya Abe. 1978. "Some Observations on the Sociology of Religion in Japan.” Japanese Journal of Religious Studies 5 (1): 5-27.

Yanagawa, Kei’ichi. 1984/1991. Gendai nihonjin no shükyō 現代日本人の宗教 (Religion of Contemporary Japanese). Kjoto: Hōzōkan.

Yzerbyt, Vincent, and Karen Phalet. 2020. "Maintaining Lockdown and Preparing an Exit Strategy: A View from Social and Behavioral Sciences." Association for Psychological Science, April 16, 2020. Accessed 12 October 2021. www.psychologicalscience.org/publications/observer/obsonline/maintaining-lockdown-and-preparing-an-exit-strategy-a-view-from-social-and-behavioral- sciences.html.

Zagefka, Hanna, and Trevor James. 2015. "The Psychology of Charitable Donations to Disaster Victims and Beyond: The Psychology of Charitable Donations." Social Issues and Policy Review 9: 155-92. 